\title{
FUNGSI BAIT SUCI BAGI UMAT PILIHAN ALLAH
}

\author{
Oleh: Teguh Bowo Sembodo, M.Th. ${ }^{1}$
}

\begin{abstract}
In religious worship, there are several elements, namely: people, personal worship, and places of worship. The Israelites as God's chosen people have used the Temple to worship Yahweh as their God. That is because of a belief that in the Temple Yahweh was present to help, bless and give them shalom. This chosen people of God greatly boast the temple they built very special. The function of the Temple in the midst of the people of Israel as a place of meeting with God, as a place of worship to the Lord.

Keywords: Temple Yahweh, chosen people of God
\end{abstract}

\begin{abstract}
Abstrak
Dalam ibadah agama, ada beberapa unsur, yaitu: orang, ibadah pribadi, dan tempat ibadah. Bangsa Israel sebagai umat pilihan Tuhan telah menggunakan Bait Suci untuk menyembah TUHAN. Itu karena keyakinan bahwa di dalam Bait Suci TUHAN hadir untuk membantu, memberkati, dan memberi mereka shalom. Umat pilihan Allah ini sangat membanggakan Bait Suci yang mereka bangun dengan sangat istimewa. Fungsi Bait Suci di tengah-tengah umat Israel sebagai tempat pertemuan dengan Tuhan, sebagai tempat ibadah kepada

Tuhan.

Kata kunci: Bait Suci, umat pilihan Allah
\end{abstract}

\section{Latar Belakang Berdirinya Bait Suci}

Tradisi nenek moyang Israel yang dicatat dalam Alkitab bahwa setiap ada peristiwa yang sakral, yaitu ada perjumpaan Tuhan dengan pribadi tertentu, atau terjadi peristiwa campur tangan Allah atas umatNya, maka disitu didirikan mezbah bagi Tuhan. Nuh mendirikan mezbah bagi TUHAN (Kejadian 8:20); Abraham mendirikan mezbah bagi TUHAN (Kejadian 12:7; 13:18; 22:9); Ishak mendirikan mezbah (Kejadian 26:25); Yakub mendirikan mezbah (33:20). Musa mendirikan sebuah mezbah (Keluaran 17:15); Yosua mendirikan mezbah di gunung Ebal (Yosua 8:33) dan di tepisungai Yordan (Yosua 22:10). Di zaman Hakim-hakim dan Raja-Raja, mezbah itu sangat penting karena mereka

\footnotetext{
${ }^{1}$ Teguh Bowo Sembodo adalah dosen tetap STT Nazarene Indonesia; Dosen Pengampu mata kuliah Teologi Sitematika dan Dogmatika.
} 
meyakini bahwa mezbah itu adalah tempat keramat karena di situ TUHAN telah hadir. ${ }^{2}$ Gideon (Hakim-hakim 6:25-28); Saul (1 Samuel 14:35); Daud (2 Samuel 24:18-25). Tradisi pendirian mezbah sebagai tempat kehadiran Tuhan yang dilakukan oleh leluhur Israel yang memiliki nama yang dikenal, tidak mudah untuk dihilangkan, dan justru mengalami perkembangan yang lebih baik. Bangsa Israel sangat mengenal tradisi kepercayaan tentang pembangunan mezbah ini sebagai tempat kehadiran Tuhan.

Jika dahulu pendirian mezbah sebagai tempat kehadiran Tuhan itu hanya dengan tumpukan batu-batu dan mereka tinggalkan, kini dalam perkembangannya, kehadiran Tuhan tersebut dalam bentuk yang lebih baik dan dapat senantiasa dekat dengan mereka.Ketika bangsa Israel keluar dari Mesir karena prakarsa dari Tuhan, mereka menjadi umat pilihan Allah dan beridah kepada-Nya secara khusus. Untuk kehadiran Tuhan mereka membangun "kemah pertemuan" (Keluaran 33:7-11; Bilangan 11:16-17; 26-30; 12:4-10; Ulangan 31:14-15). Tuhan hadir di kemah pertemuan ini untuk membimbing umat-Nya di padang gurun dengan turunnya tiang awan dan tiang api. Ketika Musa masuk kemah pertemuan tersebut, ia mendapatkan perintah-perintah dari Allah apa yang harus mereka kerjakan (Keluaran 33:9; band. Bilangan. 12:5; Ulangan 31:15). Manfaat kemah ini tentunya lebih sederhana jika dibandingkan dengan Bait Suci yang ada di Yerusalem nantinya.

Dalam kitab Bilangan, Yosua, dan 1 Samuel, memperkenalkan juga "tabut Allah" dan ini berbeda dengan kemah pertemuan di zaman Musa. Tabut Allah ini juga merupakan tempat kehadiran Allah, yang bentuknya seperti "peti” yang dapat diangkut kemana-mana dengan kayu pengusung (1 Raja-raja 8:8). Tabut ini dibawa kemana-mana supaya dekat dengan umat Israel, dengan demikian Tuhan selalu dekat dengan mereka. Ini bukan berarti TUHAN itu tidak Mahahadir. Tutupnya diberikan ornamen berupa kerub-kerub (makhluk

\footnotetext{
${ }^{2}$ Christoph Bart, Theologia Perjanjian Lama 3, (Jakarta: BPK Gunung Mulia, 1988), hal. 73.
} 
berkaki empatdan bersayap, dengan wajah manusia), di mana Tuhan semesta alam (Yahwe) dibayangkan duduk diatasnya secara tidak kelihatan. Itu berarti Tuhan bersemayam di atas kerub-kerub (1 Samuel 4:4; 2 Samuel 6:2; 1 Raja-raja 19:15). Tuhan hadir di atas tabut untuk menyelamatkan umat-Nya, untuk memberikan kemenangan terhadap musuh-musuh yang mengancam. Bandingkan Bilangan 10:35-36 "Bangkitlah, Tuhan, supaya musuhMu berserak......" Jadi tabut ini berfungsi sebagai "takhta Allah" tempat kehadiran Allah di tengah-tengah umat-Nya untuk menyelamatkan umatNya dari ancaman musuhnya. ${ }^{3}$ Homer Heater juga mengakui bahwa tabut Perjanjian itu sebagai simbol kehadiran Allah dalam peribadatan Israel. ${ }^{4}$ Tabut Perjanjian ini semakin penting artinya dalam peribadatan Israel, dan bahkan menjadi pusatnya di samping ada bukit pengorbanan.

Dalam kitab-kitab Sejarah, tersirat bahwa sebelum zaman kerajaan Israel, umat ini sudah mendirikan "bait-bait bertembok atau kuil” sebagai tempat ibadah kepada Tuhan. Muncul bait-bait di pegunungan Efraim, di Silo, dan di masa Saul dan Daud, ada kuil di Gilgal (1 Samuel 11:15), di Nod (1 Samuel 21:1), bait Yahwe di Yerusalem (2 Samuel 15:7), bukit Zaitun (2 Samuel 15:32). Sepanjang periode penyembahan Tuhan di tempat kuil tersebut, kegiatan keagamaan Israel dipusatkannya, karena di kuil itu mereka merayakan panen raya dari pertanian, dan masa raya kekeluargaan dirayakan. Pada suatu tertentu ada orang datang dengan imam untuk mempersembahkan perseorangan sebagai penggenapan nazar, untuk penghapusan dosa, untuk kasus penyakit, dan sebagainya. ${ }^{5}$ Tentu saja kuil-kuil ini tidak sama dengan Bait Suci yang paling besar di Yerusalem. Walaupun bentuknya bai-bait atau kuil tersebut tidak terlalu jelas namun ada hal tersebut memberikan imajinasi terbentuknya Bait Suci di Yerusalem.

\footnotetext{
${ }^{3}$ Ibid. hal. 74.

${ }^{4}$ Roy B. Zuck (ed), A Biblical Theology Of The Old Testament, (terjemahan), (Malang: Gandum Mas, 2005), hal. 233.

${ }^{5}$ Th. C. Vriezen, Agama Israel Kuno, (Jakarta: BPK Gunung Mulia, 1981), hal. 77
} 


\section{Bait Suci Sebagai Pertemuan Dengan Allah}

Bait Suci di Yerusalem dibangun oleh raja Saloma, putra Daud, dan keberadaannya tidak dapat dilepaskan dengan tempat peribadatan Israel pada masa yang lampau seperti mezbah, kuil, dan tabut. Daud merasa tidak pantas jika TUHAN belum ada rumah yang layak bagi-Nya, sedangkan ia sendiri di dalam rumah dari kayu aras (2 Samuel 7:2; 1 Tawarikh 17:1). Daud juga pernah bernazar tidak mau tidur, "sampai aku mendapat tempat untuk TUHAN/kediaman untuk Yang Mahakuasa dari Yakub" (Mazmur 132:2-5). Daud telah merencanakan dan mempersiapkan Bait Allah tersebut, seperti tempat, bahanbahan untuk membangun, dana untuk membangun, tenaga untuk membangun, dan lainlain (2 Tawarikh 22:2-29), namun ia tidak diizinkan oleh Tuhan untuk mendirikannya Bait Suci tersebut. ${ }^{6}$

Alasan yang diberikan dalam kitab Tawarikh bahwa Tuhan tidak mengizinkan Daud untuk membangun Bait Suci adalah, karena Daud banyak menumpahkan sangat banyak darah dan telah melakukan peperangan yang besar (1 Tawarikh 22:8; 28:3). Juga pada puncak kekuasan Daud ia telah melakukan kesalahan yang berat dihadapan Tuhan dalam peristiwa Daud memerintahkan untuk mengadakan cacah jiwa (1 Tawarikh 21:2-6). ${ }^{7}$ Salomo, putra Daud ditugasi untuk membangun Bait Suci tersebut, di Yerusalem seperti yang sudah Daud siapkan. Pembangunan Bait Suci tersebut juga mendatangkan tenaga ahli dan material dari negeri lain, terutama dalam pembuatan ukiran (ornamen) kerub, pohon korma, dan bunga mengemban (1 Raja-raja 6:29), dan singa, lembu (1 Raja-raja 7:29). Itu berarti ada pengaruh dari luar Israel untuk pembangunan Bait Suci di Yerusalem ini.

\footnotetext{
${ }^{6}$ F.L. Bakker, Sejarah Kerajaan Allah 1, (Jakarta: BPK Gunung Mulia, 1987), hal. 473-474.

${ }^{7}$ Dari pada mengagungkan Tuhan, ia lebih mengutamakan kebesarannya sendiri, kuasanya dibidang militer. Akibat kesalahnya Daud ini, seluruh Israel ditimpa musibah, malahan Yerusalem dan Daud beserta keluarganya harus menghadapi bahaya pemusnahan. Musibah itu dan terlebih penghentiannya di tempat pengirikan Ornan, itulah yang menyebabkan Daud menjadi sadar kembali akan niatnya yang semula (1 Taw. 17:1). (Christoph Bart, Theologia Perjanjian Lama 3, (Jakarta: BPK Gunung Mulia, 1988), hal. 66).
} 
Bait Suci itu dibangun di atas bukit disebelah utara Yerusalem, di sisi istana Salomo. Panjangnya sekitar 30 meter, tingginya 15 meter, dan lebarnya 10 meter. Bagian dalamnya dibagi menjadi tiga bagian ruangan: tersebut dibagi dalam ruang-ruang, yang bagian belakang (ruang yang mahakudus) adalah terbuka ke arah ruang tengah (disebut ruang kudus), tempat pelayanan kepada sang raja itu, dan ruang ini terbuka ke arah "pelataran", yakni tempat bagi para tamu. Jadi pembagian Bait Suci ini dengan segala alatnya itu justru tertuju kepada pertemuan. Di dalam ruang Maha Kudus terdapat tabut, yang dikawali oleh dua kerub besar, ditempat Kudus ada pembakaran ukupan, meja tempat roti sajian, dan disebelah kiri-kanan ada lima kandil masing-masing bercabang tujuh. Di halamam muka terdapat mazbah korban bakaran, laut dari tembaga sebagai simbol kosmis, dan sepuluh bejana pembasuhan berisi air yang digunakan oleh para imam dalam upacara penyucian. Di pintu gerbang masuk Bait Suci terdapat dua tiang besar yang dinamai Jakhin dan Boas. $^{8}$

Bait Suci yang dibangun Salomo di Yerusalem ini merupakan tempat kediaman tetap atau tempat perhentian TUHAN. Ini sesuai dengan ucapan pada saat peresmian atau pentakhbisan Bait Suci tersebut: "Sekarang, aku telah mendirikan rumah kediaman bagiMu/tempat Engkau menetap selama-lamanya" (1 Raja-raja 8:13).Tempat perhentian (menuhah) mengadung bayangan seorang musyafir yang telah mengembara dari tempat ke tempat hingga akhirnya menemui perhentian yang diharapkan. ${ }^{9}$ Ini bukan berarti bahwa Tuhan dibatasi dengan tempat bangunan indah Bait Suci, tetapi lebih mengarah ke tempat kediaman bagi Allah. Sebagaimana Salomo sebagai Raja memiliki tempat, maka Allah sebagai raja atas segala sesuatu juga harus memiliki tempat yang tetap, sebagai Istana TUHAN.

\footnotetext{
${ }^{8}$ Th. C. Vriezen, Agama Israel Kuno, (Jakarta: BPK Gunung Mulia, 1981), hal. 186-187.

${ }^{9}$ Christoph Bart, Theologia Perjanjian Lama 3, (Jakarta: BPK Gunung Mulia, 1988), hal. 77.
} 
Menurut catatan Vriezen, Bait Suci di Yerusalem ini dianggap Rumah Yahwe, tempat Yahwe tinggal di tengah-tengah umat-Nya. Dalam hal itu perlu dicatat bahwa teologia golongan Deuteronomis pada zaman kemudian dengan lebih hati-hati mejelaskan bahwa bukan Yahwe melainkan "Nama Yahwe" yang bertempat tinggal di situ. Dengan pernyataan yang demikian teratasilah ketegangan antara konsep bahwa Yahwe tinggal di Bait Suci, tinggal di Sorga, tinggal di gunung Sinai. Dengan adanya penjelasan bahwa nama Yahwe bertempat tinggal di Bait Suci, maka jelaslah bahwa Yahwe sendiri hadir di Bait Suci, namun kepribadian-Nya jauh melampaui batas-batas tembok gedung. ${ }^{10}$ Homer Heater memberikan penjelasan tentang Bait Suci tersebut sebagai berikut:

Karena TUHAN bersifat Universal dan Mahahadir, adalah bodoh bila mengasumsikan bahwa Dia dapat dibatasi pada kuil atau tempat suci yang bersifat lokal (1 Raja-raja 8:27). Pada saat bersamaan TUHAN penuh dengan kemurahan mengakui untuk menaruh namaNya di Bait Suci. Karena hal itu adalah benar, maka orang mestinya dapat berdoa ke arah Bait Suci dan mengharapkan tanggapan dari Allah yang mengidentifikasikan diriNya dengan Bait Suci. Karena Bait Suci yang sebenarnya ada di sorga, maka dari sanalah Dia akan mendengarkan doa-doa yang dipanjatkan ke arah Bait Suci yang ada di bumi (1 Raja-raja 8:30). Tetapi sayang konsep tentang Allah Universal yang menyatakan diri-Nya melalui tempat suci lokal menjadi ruak atau menyimpang. Tempat suci itu sendiri mendapat arti pentingnya yang melebihi porsinya; bangsa itu yakin bahwa selama tempat suci itu berdiri, Allah tidak akan menghukum kota itu. ${ }^{11}$

Pemikiran teologis dari Homer Heater ini sangat tepat sekali untuk dipegang oleh umat pilihan Allah masa kini berkaitan dengan Allah yang Universal itu tidak hanya tinggal di Yerusalem, tetapi Ia dapat hadir di mana-mana. Tidak perlu ke Yerusalem untuk mencari Allah di sana, tetapi di sinipun kita dapat beribadah kepada Allah.

Bait Suci sebagai tempat Kerajaan Allah merupakan tempat pertemuan Allah dengan raja (raja Israel). Begitu pentingnya tokoh raja bagi bentuk bait itu, dapat dilihat dari hubungan yang rapat antara letak kolasi Bait Suci dan istana raja. Kedua bangunan tersebut letaknya berdampingan, sehingga merupakan dua bagian dari satu keseluruhan (1

\footnotetext{
${ }^{10}$ Ibid, hal. 187.

${ }^{11}$ Roy B. Zuck, A Biblical Theology Of The Old Testament (terjemahan), (Malang: Gandum Mas, 2005), hal. 235.
} 
Raja-raja 9:10). Raja itu sebagai orang nomor satu untuk menghampiri Bait Suci, dan raja bertindak sebagai imam terkemuka (1 Raja-raja 8:5; 62-66; 9:25), maka sebenarnya sudah tercapai dan terwujudlah maksudnya dengan pembangunan Bait Suci itu. Kedaulatan Salomo sebagai "tuan rumah" nampak juga dari pengangkatan Zadok menjadi kepala imam untuk seterusnya (1 Raja-raja 2:35). Di samping raja sendiri hanya para imam itu saja yang diperbolehkan memasuki ketiga ruangan Bait Suci. Pembatasan tersebut justru menekankan fungsi raja dan para imam selaku penengah atau pengantara bagi seluruh umat.

Setelah Salomo wafat, Bait Suci di Yerusalem ini masih berdiri kokoh hingga tiga abad lebih lamanya. Dengan perjalanan waktu yang cukup lamatentulah membutuhkan pemugaran dan pembaruan bahkan suatu reformasi. Peristiwa-peristiwa sejarah seperti perpecahan kerajaan antara Utara dan Selatan, merosotnya kerajaan Yehuda, pergolakanpergolakan dalam negeri dan terutama pemberitaan para nabi yang semakin gawat semuanya itu membangkitkan suatu pemikiran ulang tentang makna dari Bait Suci, dan muncul pengertian-pengertian baru. Tidak mungkin gedung Bait Suci itu dimegahkan dan dihormati sebagai "rumah kediaman TUHAN" dan "bait kerajaan" dengan begitu saja, sesuai dengan faham pembangunannya dan angkatan-angkatan umat yang pertama.

Bait Suci sebagai tempat kediaman TUHAN dalam perkembangan maknanya, pertama, munculnya konsep Bait Suci sebagai "kediaman bagi nama TUHAN" pastilah ada sebab-sebabnya di dalam sejarah kesadaran umat akan kekudusan Allah. Lain jenis kesadaran itu pada awal zaman kerajaan, lain lagi menuju akhir zaman ini. Kehadiran TUHAN di kuil Silo, Betel, Dan, Samaria maupun Yerusalem, tadinya dianggap seolaholah sudah terjamin dengan sendirinya. Dengan adanya kerajaan Utara sudah lenyap, kuilkuil yang sangat dihormati juga sudah merosot kesakralannya, kerajaan Yehuda makin terancam oleh kekuasaan-kekuasaan asing, dan pemberitaan para nabi - terutama Amos 
dan Hosea, Yesaya dan Mikha pada abad ke-8, Yeremia dan Zefanya abad ke-7 sebelum Masehi, semakin gawat, maka kepercayaan itu gocang sedikit demi sedikit. Di sana-sini timbullah kesadaran, bahwa sesungguhpun TUHAN berkenan hadir di tengah-tengah umat-Nya, tetapi di dalam kehadiran-Nya itu tetap kudus, mulia dan bebas, jadi tidak terikat kepada bangsa, tempat dan bait yang dimanapun juga. Hosea memberitakan bahwa TUHAN itu "Allah dan bukan manusia/Yang Kudus di tengah-tengah kamu” (Hosea 11:9); Yesaya mengungkapkan nubuatannya tentang "Yang Kudus, Allah Israel" (Yesaya $5: 16 ; 17: 7 ; 30: 15 ; 31: 1)$. Yeremia mempertahankan kepercayaan bahwa "ini bait TUHAN, bait TUHAN, bait TUHAN" (Yeremia 7:4). Kesadaran baru mengenai ketetapanketetapan tempat ibadah yang satu berakar di dalam kesadaran baru akan keesaan Allah orang Israel bernama TUHAN (bandingkan Ulangan 12:1-28). ${ }^{12}$

Kedua, gagasan "kehadiran nama TUHAN" sering ditafsirkan, seakan-akan bukan TUHAN sendiri, melainkan hanya nama-Nya itulah yang hendak dikatakan hadir/diam/tinggal di atas bumi, khususnya di dalam Bait Suci. Penafsiran ini di dasarkan kepada pertimbangan, bahwa menurut konsepsi yang kanon baru muncul terkemudian, TUHAN sendiri berkediaman tetap di sorga, sedangkan di atas bumi ini, Ia menetapkan nama-Nya sebagai wakil yang berwibawa penuh, namun harus dibedakan dari Dia sendiri. Nama TUHAN itu tidak lain dan tidak kurang dari pada TUHAN sendiri. Harus ditegaskan bahwa ungkapan-ungkapan tentang kehadiran nama TUHAN itu justru lebih menekankan kehadiran TUHAN di dalam keluhuran-Nya yang dasyat. Dengan nama TUHAN yang hadir, maka itu berarti bahwa TUHAN sendiri hadir di dalam kekudusanNya, selaku Allah orang Israel yang bebas dan berdaulat, mengatasi segala ilah yang disembah bangsa-bangsa. Tekanan baru pada "nama TUHAN" ini ada sangkut pautnya dengan hal semakin dalamnya kesadaran bahwa ibadah orang Israel yang sudah sesat itu

\footnotetext{
${ }^{12}$ Christoph Bart, Theologia Perjanjian Lama 3, (Jakarta: BPK Gunung Mulia, 1988), hal. 80-81.
} 
perlu diperbarui secara radikal (band. Reformasi Hizkia di 2 Raja-raja 18:4, dan reformasi Yosia, 2 Raja-raja 22-23). ${ }^{13}$

Ketiga, konsepsi Bait Suci selaku "kediaman bagi nama TUHAN" itu dibarengi oleh suatu pengertian baru terhadap fungsi tabut Allah. Benda suci itu berada di ruang belakang (maha kudus), di naungi oleh sayap kerub-kerub, yang tadinya menjadi lambang kehadiran Allah secara tidak kelihatan, sesuai dengan peranannya sebelum mendapatkan tempat perhentian yang tetap. Ketika Yosia berkuasa dalam pemerintahan (2 Raj. 22-23), rupanya tabut itu mendafatkan fungsi yang baru, yaitu sebagai tempat menyimpan loh-loh sepuluh hukum Allah. Kesaksian Alkitab yang ditulis sejak masa itulah yang memulai membiasakan bayangan dan sebutan baru bagi tabut itu, yakni sebagai "tabut perjanjian TUHAN", di mana kata "perjanjian" memeiliki pengertian yang sama dengan "ketetapan" atau peraturan yang wajibkan oleh TUHAN untuk dilakukan oleh umat-Nya. ${ }^{14}$

Tabut Allah selaku "tabut perjanjian TUHAN" menjadi lambang kehadiran Allah di dalam bait-Nya. Kehadiran Allah kini dialami secara baru. Dengan perubahan nama dan fungsi tabut itu ditekankan kehadiran TUHAN, allah orang Israel sejak Mesir, di dalam firman-Nya, di dalam segala perintah-perintah dan ketetapan-Nya, dan di dalam persekutuan dengan umat-Nya. Bukannya karena berkat yang diberikan dan perlindungan saja, tetapi kuasa firman-Nya itulah yang kini diketengahkan. Dapat dikatakan, tabut itu kini sudah mulai berfungsi seperti gulungan Taurat di rumah-rumah kebaktian Yahudi (sinagoge). Fungsi yang baru ini pastilah ada hubungannya dengan konsepsi Bait Suci sebagai tempat kediaman nama TUHAN; bukankah nama-Nya itulah TUHAN sendiri, TUHAN yang hadir untuk berfirman, untuk menyatakan segala janji dan tuntutan-Nya, seperti yang terukir pada loh-loh di dalam tabut.

\footnotetext{
${ }^{13}$ William Dyrness, Tema-Tema Dalam Teologi Perjanjian Lama (terj), (Malang: Gandum Mas, 2001), hal. 125.

${ }^{14}$ Ibid. hal. 125 .
} 
Keempat, semakin kuatnya keyakinan umat Israel bahwa Bait Suci sebagai kediaman bagi nama TUHAN, mempunyai suatu akibat lagi, yaitu bangkitnya kesadaran bahwa seharusnya jumlah Bait Suci itu hanya satu saja. Konsekuensi ini sebenarnya tidak masuk akal, namun umat Israel sejak dulu kala berpaut kepada pluralisme tempat ibadah. Allah menampakkan diri-Nya di beberapa tempat, bapa-bapa leluhur telah mendirikan mezbah-mezbah, dan angkatan-angkatan yang kemudianpun mendirikan kuil-kuil dari Dan sampai Bersyeba. Yerusalem terpilih sebagai kota Allah dan kota Daud, dan alasan tersebut tidak cukup kuat untuk berpindah dari pluralisme kepada sentralisme. Sesungguhnya umat Israel pada waktu itu beribadah di Yerusalem, namun mereka memiliki hak untuk beribadah di luar Yerusalem. ${ }^{15}$

Bukannya ide sentralisasi itu mutlak, melainkan suatu keinsyafan baru akan kehendak TUHAN, dan itulah yang menggerakkan umat itu untuk berubah pikiran. Pemberitaan para nabi, berisi kecaman terhadap banyaknya tempat ibadah dan hal tersebut dianggap kemerosotan tanggapan mereka terhadap TUHAN yang esa. Oleh gerakan pembaruan, disiarkanlah tuntutan ilahi, supaya cara beribadah itu dipusatkan kembali kepada Allah yang esa. "Dengarlah, hai orang Israel! TUHAN itu Allah kita, TUHAN itu esa (Ulangan 6:4). Besar kemungkinannya bahwa keesaan Allah yang baru ditemukan kembali itu, kini menjadi pendorong untuk melepaskan kemajemukan ibadah yang menjadi perangkap itu. Dengan bergeraknya waktu, makin nyaringlah terdengar tuntutan sentralisasi ibadah di dalam Bait Suci yang tunggal, yakni di tempat yang satu-satunya yang dipilih Allah menjadi kediaman bagi namaNya (Ulangan 12). Pelaksanaan sentralisasi ini terjadi pada masa pemerintahan Yosia atas Yehuda (2 Raja-raja 22-23).

Bait Suci di Yerusalem yang dibangun Salomo ini pernah dihancurkan oleh Nebukadnezar, dari Babel. Peralatan dalam Bait Sucidiangkut ke Babel, beserta tawanan,

\footnotetext{
${ }^{15}$ Christoph Bart, Theologia Perjanjian Lama 3, (Jakarta: BPK Gunung Mulia, 1988), hal. 79
} 
dan mereka sebagai orang buangan. Hukuman tersebut terjadi karena dosa yang telah dilakukan oleh Israel dan Yehuda. Namun ketika mereka pulang dari pembuangan, mereka membangun kembali Bait Suci di Yerusalem yang sudah menjadi reruntuhan tersebut. Dengan munculnya Bait Suci yang baru yang dibangun oleh Zerubabil dan rekanrekannya, muncul persepsi baru tentang Bait Suci ini.

Pertama, dasar pemikiran baru ini diambil dari penglihatan Yehezkiel mengenai Bait Suci, dalam Yehezkiel 1-3; 8-11 tentang Bait Suci lama; sedangkan 40-48, tentang Bait Suci baru yang dijanjikanAllah untuk masa depan. Ketiga penglihatan tersebut berkenaan dengan soal hadir tidaknya TUHAN di dalam Bait Suci-Nya. Masalah ini menjadi isu baru secara mendadak, tatkala bait yang lama terbakar habis, dan TUHAN meninggalkantempat kudus-Nya (Ratapan 2:7). Sebenarnya tidaklah demikian. Ketiga penglihatan Yehezkiel ini menunjukkan suatu kesadaran dan pengertian baru terhadap Bait Suci. Jauh sebelum musibah menimpa Yerusalem sudah menjadi fakta, nabi itu menyadari bahwa TUHAN tidak pernah terikat oleh janji-Nya, melainkan selalu bebas di dalam kehadiran-Nya. Datangnya dan hadirnya kemuliaan TUHAN adalah peristiwa yang ajaib, bukannya suatu keadaan yang terjamin dengan automatis. Allah memelihara kasih dan setia-Nya,tetapi di dalam menyatakan kasih-Nya itu Ia tetap bebas dan kudus. Jika tadinya nabi itu tertegun melihat kemuliaan TUHAN pergi meninggalkan bait-Nya yang lama, maka nabi lebih terheran lagi bahwa Dia yang sebebas dan sekudus itu berkenan hadir kembali di dalam bait-Nya yang baru. ${ }^{16}$

Kedua, tradisi Alkitabiah mengenai Kemah Suci yang besar, khususnya dalam kitab-kitab Keluaran, Imamat, dan Bilangan, harus dilihat dari latar belakang situasi zaman pembuangan, dimana kelompok kaum imam-imam menggumuli pembaruan ibadah, dengan suatu bait yang baru sebagai pusatnya. Mereka memperoleh keyakinan bahwa

\footnotetext{
${ }^{16}$ Ibid, hal. 85-87.
} 
dasar pembaruan itu tidak usah dicari-cari dari jauh, bukankah Allah sendiri telah lama menyediakannya? Bukankah dalam penyataan-Nya di atas gunung Sinai pada awal sejarah Israel, Ia telah meletakkan dasar itu? Dengan tidak ragu-ragu lagi mereka menarik kesimpulannya: kemah suci yang pernah merupakan tempat ibadah bapa-bapa leluhur Israel di padang gurun, hendaknya menjadi pedoman dan sumber inspirasi dalam perencanaan Bait Suci, bilamana sebentar lagi umat itu sempat dan rela untuk mendirikannya kembali.

Fungsi kemah tersebut sebagai "rumah bagi TUHAN", dan pertemuan bebas antara TUHAN dengan umat-Nya, langsung atau dengan perantaraan Musa (Kel. 25:22; 29:42-43; Im. 1:1). Kedua fungsi kemah yang berbeda agaknya dianggap untuk saling melengkapi. Bait yang baru itupun supaya memenuhi kedua fungsi yang saling melengkapi tersebut, yaitu sebagai tempat kehadiran dan kediaman TUHAN, namun terutama sebagai tempat pertemuan, tempat pemberian firman-Nya.

Kemah Suci tersebut dapat diangkat dan dipindahkan dari tempat ke tempat lain merupakan unsur pembaruan ibadah. Namun dalam bayangan, bahwa Bait Suci yang baru itu akan berbentuk gedung dan akan bertempat di Yerusalem. Sebagai unsur pembaruan, patutlah dicatat bahwa kemah suci itu acap kali dikatakan berada di tengah-tengah umat yang sedang berkemah. Hal ini menunjukkan unsur begitu eratnya pergaulan antara Tuhan dengan umat-Nya. Pergaulan dan persekutuan yang rapat dengan Allah, itulah yang dihayati Israel. $^{17}$

Ketiga, sehubungan dengan "Kemah Suci" atau "Kemah Pertemuan", kalangan imam pada zaman pembuangan memperoleh keyakinan akan perlunya suatu pembaruan lagi, yakni "menyangkut ruang yang Maha Kudus" dalam Bait baru. Ruang Maha Kudus ini diperuntukkan kehadiran Allah: dua kerub besar dibayangkan menjadi "alas" atau

\footnotetext{
${ }^{17}$ Ibid, hal. 88-89
} 
"kendaraan" bagi TUHAN yang bersemayang di atas kerub (1 Samuel 4:4; 2 Samuel 6:2; 2 Raja-raja 19:15; Mazmur 80:2; 99:1). Sedangkan tabut Allah ditempatkan tepat dibawah sayap kerub-kerub (1 Raja-raja 8:6). Keadaan ruang ini berakhir dengan peristiwa keruntuhan bait Salomo, dimana para kerub dan tabut itu lenyap, tetapi kelak akan dipulihkan kembali seperti keadaansemula. ${ }^{18}$

Ketiga fungsi Bait Suci yang baru tersebut jikalau dibandingkan dengan Bait Suci Israel secara teologis fungsi berkaitan dengan kehadiran Allah mengalami perkembangan, walaupun tidak terlalu significan. Tentu saja hal tersebut disebabkan karena pengalaman mereka dengan TUHAN selama dalam pembuangan dan tindakan TUHAN dalam pemulangan.

\section{Bait Suci Sebagai Tempat Ibadah kepada Allah}

Kehadiran TUHAN di Bait Suci mengundang umat-Nya untuk datang bertemu dan beribadah kepada-Nya, itu sebabnya Bait Suci iti diberi bentuk untuk tempat pertemuan TUHAN dengan umat-Nya. Pertemuan ini dianggap sakral tergantung pada kehadiran TUHAN dalam pertemuan tersebut. Anugrah Allah yang bebas ini terus dipegang dalam ingatan dalam pelaksanaan ibadah yang selanjutnya bagi umat Allah.

Dalam ibadah yang dilakukan oleh Israel ini nilai penting yang terungkap adalah "bertemu dengan TUHAN". Makna ini dapat dilihat dari:

Pertama, barang siapa yang mau beribadah, tentunya ada kemauan untuk berangkat dari tempatnya yang biasa, bergerak dan melangkah ke tempat ibadah yang hendak dikunjungi. Haruslah ia "pergi”, "berjalan”, "mendekat", sampai "masuk" ke tempat itu. Kata "pergi, berjalan, mendekat, masuk ini mempunyai makna yang penting dalam ibadah. Bandingkan dengan: "pergi” (Yesaya. 30:29); "datang untuk sujud” (Yeremia 26:2; 1 Samuel 1:3; Mazmur 122:1); "mendekat" (Mazmur 65:5; Imamat 9:5). Nampaknya "pergi,

\footnotetext{
${ }^{18}$ Ibid, hal. 89-90
} 
datang, masuk, dan mendekat" tidak semata-mata merupakan pendahuluan atau persiapan dalam ibadah. Meninggalkan tempatnya yang fana dan masuk kehadirat TUHAN, berarti umat itu menyeberang dari dunianya sendiri ke dunia Allah yang berkenan hadir bumi. "Beribadahlah kepada TUHAN dengan sukacita, datanglah ke hadapan-Nya dengan soraksorai!" (Mazmur 100:2). Dengan demikian satu dengan yang lain tak dapat dipisahkan. ${ }^{19}$

Kedua, ibadah tempat kehadiran TUHAN selalu disertai dengan rasa hormat dari umat itu. Mengaku kerendahan diri dan kemuliaan Allah dengan berbagai-bagai cara, sudah tentu merupakan unsur ibadah yang tak boleh kurang. Cara-cara yang paling lazim adalah mengagungkan nama TUHAN dan sujud menyembah. Cara-cara menunjukkan hormat ini merupakan adat kebiasaan melulu, dan bangsa Israel memakainya sejak dulu kala, dengan tidak pernah menanyakanasal-usulnya. Para nabi sewaktu-waktu memperingatkan, bahwa pelaksanaan tanda-tanda lahirian ini belum tentu membuktikan adanya rasa hormat yang sesungguhnya. "Bangsa ini datang mendekat dengan mulutnya/ dan memuliakan Aku dengan bibirnya/padahal hatinya menjauh dari padaKu/ dan ibadahnya kepadaKu/hanya perintah manusia yang dihafalkan (Yesaya 29:13). "Bukan setiap orang yang berseru kepada-Ku: Tuhan, Tuhan! akan masuk ke dalam Kerajaan Sorga, melainkan dia yang melakukan kehendak Bapa-Ku yang di sorga" (Matius 7:21). Menghormati Allah dengan jujur dan sungguh-sungguh, adalah amal yang tidak mudah dikerjakan dan hal itu yang dikehendaki Allah. ${ }^{20}$

Ketiga, sehubungan dengan ibadah di halaman suci, data Alkitab menyinggung tentang "wajah TUHAN." 21 Hampir seluruh kegiatan ibadah Israel dapat dikatakan berkisar pada wajah TUHAN. Jika tadinya Bait Suci itu sifatnya sebagai "tempat pertemuan”, dan “ibadah itu sebagai pertemuan dengan Allah”, maka kini harus ditambah

${ }^{19}$ David M. Howard Jr. An Introduction To The Old Testament Historical Book, (Chicago: Moody Press, 1993), hal. 261.

${ }^{20}$ Ibid. hal. 261-262

${ }^{21}$ Menghadap wajah-Nya (Mzr. 95:2); mencari wajah-Nya (Mzr 24:6; 27:8; 105:4; Hos 5:15); memandang wajah-Nya (Mzr 11:7; 17:15). 
bahwa dalam ibadahnya itu umat sungguh-sungguh berhadapan muka dengan TUHAN. Wajah TUHAN itu sudah tentu bertepatan maknanya yang lebih khusus dan tidak dapat diartikan dengan bertemu "TUHAN sendiri secara langsung." Pertemuan dengan TUHAN ini merupakan pengalaman luar biasa, dahsyat dan berbahaya di satu pihak, mesra dan penuh sukacita di lain pihak. Pengunjung Bait Suci menghadapi mezbah, dua kerub, dan tabut Allah. Ada ribuan umat dan para Imam dan orang Lewi melaksanakan tugasnya dengan cermat. Mereka menikmati persekutuan orang-orang percaya, namun di tengahtengah persekutuan ini, mereka diperkenankan untuk melihat dan menghayati Allah secara pribadi dalam kehadiran TUHAN. Mampu atau tidak mengatasi kebutaannya sendiri, mereka boleh bertemu langsung dengan Yang Maha Kudus, melibatkan jiwa raga, untuk mengecap dan melihat, betapa baiknya TUHAN itu. Allah yang sudi membuat diri-Nya dirasai dan dihayati - Dia itulah yang rupanya dimaksud dengan "wajah TUHAN."

Keempat, ibadah di Bait Suci dengan membawa persembahan. Tidak pernah orang Israel datang beribadah dengan tangan hamba tidak membawa persembahan. "Janganlah orang menghadap hadirat TUHAN dengan tangan hampa" adalah ketetapan dasar bagi ibadah Israel (Keluaran 23:15; 34:20; Ulangan 16:16-17). Sebelum umat membawa persembahan, TUHAN telah siap untuk memberikan diri-Nya untuk menjadi Allah mereka (Kejadian 17:7-8). Pemberian Allah yang tidak terkatakan tentunya mendahuluinya dan mengatasi segala usaha dari pihak manusia. Prioritas persembahan umat yang sungguhsungguh tercantum dalam wujud ibadah orang Israel. ${ }^{22}$

Segala jenis persembahan - biarpun berupa korban sembelihan, sajian, benda, logam atau uang - diperuntukkan bagi TUHAN, Yang Mahakudus, Allah Israel. Dia yang "lebih dahsyat dari pada segala allah (Mazmur 96:4). Disinilah letak perbedaan dengan paham persembahan di dalam agama-agama dunia lainnya. Nilai persembahan-persembahan

\footnotetext{
${ }^{22}$ Christoph Bart, Theologia Perjanjian Lama 3, (Jakarta: BPK Gunung Mulia, 1988), hal. 96-97.
} 
kepada Allah yang semulia itu tentu saja nilainya tidak terbatas. TUHAN tidak membutuhkan santapan ataupun pemberian apapun dari umat-Nya (band. Yesaya 43:2324; Mazmur 40:7; 50:7-15; 51:18-19). Para nabi dengan tidak ragu-ragu mengungkapkan apa yang sebenarnya dituntut oleh TUHAN (Mikha 6:8): persembahan-persembahan yang mencerminkan penyerahan diri umat-Nya kepada pengabdian yang rela dan setia, dengan segenap hati, dengan seluruh tindak-tanduknya - bukan hanya selama kebaktian, tetapi di dalam kehidupan sehari-hari. TUHAN menolak seluruh cara beribadah ini, apabila umatNya membiasakan korban-korban yang curang.

Dalam beribadah umat Israel ini bukan di dasarkan atas perintah, atau karena takut terkena hukuman, kalau kuwajiban tersebut diabaikan. Pada hakekatnya mereka beribadah juga dengan sopan: bukannya disuruh atau diancam, melainkan karena dorongan hati yang sewaktu-waktu timbul dengan tidak disengaja. Doa-doa yang dipanjatkan dari mana saja, namun terutama dari tempat-tempat pertemuan dengan TUHAN, dan khususnya di Bait Suci Yerusalem (bandingkan doa pentakhbisan Biat Susi oleh Salomo, 1 Raja-raja 8:2753). Pada suatu hari Bait Suci akan disebut rumah doa bagi segala bangsa (Yesaya 56:7; Matius 21:13). Doa tersebut berkaitan dengan rupa-rupa penderitaan dan kesesakan yang sedang dialami oleh umat itu, kadang-kadang juga menjadi pendorong dalam beribadah. Dalam ibadah kadang-kadang disertai sikap badan, perbuatan-perbuatan, upacara-upacara tertentu. Ada suara yang diucapkan secara pribadi maupun bersama. ${ }^{23}$

Ibadah di Bait Suci ini tidak hanya menaikkan doa, namun juga pengucapan syukur kepada TUHAN atas perbuatan-Nya ang besar. Jenis ibadah syukur ini mempunyai latar belakang yang cukup jelas. Allah telah mendengar doa permintaan seseorang, telah menyembuhkan, membebaskan atau menyelatkan seseorang dari kesesakan. Ucapan syukur berhubungan nazar yang telah diucapkan pada waktu ia berseru memimnta

\footnotetext{
${ }^{23}$ Willian Dyrness, Tema-Tema Dalam Teologi Perjanjian Lama (terj), (Malang: Gandum Mas, 2001), hal. 124.
} 
pertolongan, dan masuklah ia ke halaman suci untuk mengucapkan syukur kepada Allah. Walaupun ucapan syukur itu pribadi, namun dihadiri oleh jemaat yang lain, sehingga peristiwa pribadi tersebut berubah menjadi umum. Oleh sebab itu ucapan syukur ini merupakan jenis ibadah orang Israel.

Pengucapan syukur kepada TUHAN terdiri atas suatu ungkapan lidah yang singkat, disertai oleh suatu perbuatan, yakni "mempersembahkan korban syukur. Kata syukur dan korban syukur merupakan kesatuan yang tidak dapat dipisah-pisahkan. Ucapan syukur ini mengandung dua segi, yaitu ucapan lidah, dan segi lain adalah perbuatan tangan yang berupa perembahan. Persembahan tangan ini harus ada, namun lengkap apabila orang yang memberinya menyatakan maksud pemberian tersebut.

Kata syukur dan korban syukur yang keduanya terkait satu sama lain, hanyalah merupakan tanda terima-kasih semata-mata, jadi pada dirinya belum tentu menyatakan penghargaan yang wajar terhadap kebaikan yang dialami seseorang. Beberapa ungkapan pemazmur menunjukkan keinsyafan bahwa tradisi yang berabad-abad itu belum mutlak sifatnya. Mengucap syukur dan membayar nazar itu kepada TUHAN ada kalanya boleh juga dalam bentuk pengabdian diri dengan sungguh-sunggu, pengabdian itu justru merupakan intinya pada masa lalu. "Siapa yang mempersembahakan syukur sebagai korban, ia memuliakan Allah, siapa yang jujur jalannya, keselamatan akan diperlihatkan kepadanya (bandingkan Mazmur 50:23).

Satu pokok penting lagi yang tidak dapat ditinggalkan orang datang beribadah ke Bait Suci adalah "umat hendak menaikkan puji-pujian kepada TUHAN. Suatu ibadah puji-pujian merupakan panggilan Tuhan terhadap umat-Nya untuk berkumpul di hadapanNya, dan untuk memuliakan nama-Nya. Ibadah puji-pujian - demikianlah kita belajar dengan maksud hendak memperkenalkan dan menyiarkan kebesaran Allah. Mengumumkannya sebagai berita kesukaan bagi setiap makhluk di bawah langit, sambil 
mengajak segala yang bernafas untuk dengan sukarela ikut serta dalam puji-pujian itu, ikut serta menikmati kebaikan Allah. Umat Israel melaksanakan tugasnya seraya meneruskan ajakan dan undangan ini dengan tidak mengenal lelah. Allah sendiri berkenan dipuji, malah Ia mengajak manusia untuk menghormati-Nya, karena di dalampujian itu letaknya rahasia kebahagiaan manusia. $^{24}$

Bait Suci itu merupakan tempat dimana keadilan dilaksanakan. Orang-orang yang diperlakukan tidak adil itu harus dapat datang ke tempat di mana TUHAN menempatkan nama-Nya dan berseru memohon keadilan dan mengharapkan pembuktian kebenaran (1 Raja-raja 8:21). Pernyataan itu mencerminkan bahwa keadilan mendapatkan penekanan kuat dalam teologi Perjanjian Lama, karena TUHAN itu adil, Dia mengharapkan wakilwakil-Nya juga adil. Bait Suci merupakan tempat di mana keadilan mendapatkan pengakuan. $^{25}$

Seperti halnya sebelum dibangunnya Bait Suci di Yerusalem, ketika umat mengalami kekalahan sewaktu melawan musuh, sebagai tanda bahwa Tuhan tidak berkenan kepada mereka. Demikian juga ketika Bait Suci Yerusalem dibangun, mereka datang ke Bait Suci ini untuk mengakui dosa-dosa mereka. Salomo berdoa memohon TUHAN mengampuni mereka dan mengembalikan ketanah yang telah Kuberikan kepada nenek moyang mereka (1 Raja-raja 8:34).

\section{Penutup}

Bait Suci yang dibangun di Yerusalem, keberadaannya tidak dapat dilepaskan dengan mezbah yang dibangun oleh bapa-bapa beriman, dengan kemah pertemuan di zaman Musa ketika berada di Padang Gurun, dan juga kuil-kuil serta Tabut Perjanjian milik Israel. Bait Suci Israel dibangun oleh Salomo, namun perancangnya adalah Daud.

\footnotetext{
${ }^{24}$ Ibid. hal. $125-126$

${ }^{25}$ Roy B. Zuck (ed), A Biblical Theology Of The Old Testament (terjemahan), (Malang: Gandum Mas, 2005), hal. 134.
} 
Secara teologis Bait Allah di Yerusalem ini merupakan tempat kehadiran Allah, dimana Allah hadir dan dekat umat-Nya, maka akan ada pertolongan TUHAN, ada pembebasan, ada keselamatan, dan kemenangan dari musuh-musuhnya. Itu juga tidak berarti TUHAN itu dikurung dalam rumah TUHAN sehingga tidak dapat pergi kemana-mana, dan selalu menjaga Israel, namun TUHAN itu Mahahadir dan tidak tidak dapat dibatasi oleh ruang dan waktu. Ia dapat hadir di mana-mana dalam waktu yang sama.

Bait Suci yang dibangun oleh Salomo ini mengalami kerusakan ketika dihancurkan oleh Nebudkanezar dari Babil, namun Bait Suci yang baru, yang dibangun oleh Zerubabil ini mengalami perkembangan makna teologis, karena pengalaman mereka yang baru, setelah pulang dari pembuangan. Tetapi pada dasarnya maknanya tidak meninggalkan makna yang dulu.

Bait Suci sebagai tempat kehadiran TUHAN yang bertakhta dan dekat dengan Israel, menjadikan Israel beribadah untuk menyembah TUHAN di Bait Suci ini. Ibadah yang dijalankan oleh Israel ini disebabkan karena mereka melihat perbuatan TUHAN dalam menolong mereka, memberkati mereka, dan menjadikan mereka hidup dengan damai sejahtera. Dalam ibadah di Bait Suci ini umat Israel menaikkan pujian kepada Allah, menaikkan ucapan syukur, dan juga membawa persembahan sebagai bukti ucapan syukur mereka kepada TUHAN. 


\section{DAFTAR PUSTAKA}

Bakker, F. L. Sejarah Kerajaan Allah 1, Jakarta: BPK Gunung Mulia, 1987.

Bart, Christoph. Theologia Perjanjian Lama 3, Jakarta: BPK Gunung Mulia, 1988

Dyrness, William. Tema-Tema Dalam Teologi Perjanjian Lama (terj), Malang: Gandum Mas, 2001.

Howard Jr, David M. An Introduction To The Old Testament Historical Books, Chicago: Moody Press, 1993.

Vriezen, Th. C. Agama Israel Kuno, Jakarta: BPK Gunung Mulia, 1981.

Zuck, Roy B. (ed), A Biblical Theology Of The Old Testament, (terjemahan), Malang: Gandum Mas, 2005. 